\title{
THE ABOLITION OF THE MANDATORY DEATH PENALTY IN AFRICA: A COMPARATIVE CONSTITUTIONAL ANALYSIS
}

\author{
Andrew Novak
}

\section{INTRODUCTION}

The mandatory death penalty for the crime of murder is in rapid retreat worldwide. Originally diffused to the common law countries of the Caribbean, Africa, and South and Southeast Asia by way of the British Empire, the penalty has been found unconstitutional and incompatible with human rights norms in at least ten Caribbean nations since the year 2000. A new wave of litigation has appeared in the postcolonial common law nations of East and Southern Africa, and courts in Malawi, Uganda, and now Kenya have found an automatic sentence of death unconstitutional and have replaced mandatory schemes with discretionary ones that allow consideration of mitigating factors in the capital sentencing process. ${ }^{1}$ The resulting criminal justice regimes operate in closer conformity with international human rights norms and explicitly adopt these norms in their domestic legal systems.

This harmonization of death penalty regimes across borders is no accident: it was the deliberate intention of a small network of international antideath penalty advocates to create a body of transnational jurisprudence from which to draw in bringing incremental challenges in national courts. ${ }^{2} \mathrm{By}$ initially petitioning the United Nations Human Rights Committee and the InterAmerican Human Rights System to find the mandatory death penalty incompatible with human rights treaty obligations, this core of advocates succeeded in developing a corpus of persuasive reasoning on which they could

* Adjunct Professor of African Law, American University Washington College of Law. The author has a Juris Doctor, Boston University School of Law, and a Master of Science (Hons.), African Politics, London School of Oriental and African Studies. He is currently Associate Counsel at the United States Board of Veterans' Appeals. He appreciates the assistance of Dr. Jesse Fecker, Ph.D., J.D., on an earlier draft of this Article and the support of the Death Penalty Project UK to attend a litigation strategy session in Nairobi, Kenya, in March 2011. The views expressed in the Article, however, reflect those of the author alone.

1. Andrew Novak, Constitutional Reform and the Abolition of the Mandatory Death Penalty in Kenya, 45 SUFFolK U. L. REV. 285 (2012) [hereinafter Novak, Kenya]; Andrew Novak, The Decline of the Mandatory Death Penalty in Common Law Africa: Constitutional Challenges and Comparative Jurisprudence in Malawi and Uganda, 11 LOY. J. PUB. INT. L. 19 (2009) [hereinafter Novak, Malawi Uganda].

2. This strategy is driven by the Death Penalty Project UK and its executive directors Saul Lehrfreund and Parvais Jabbar as well as their partners on the ground. Interview, Litigating Against the Death Penalty for Drug Offences: An Interview with Saul Lehrfreund and Parvais Jabbar, 1 INT'L J. HUM. RTS. \& DRUG POL'Y 53, 54-55 (2010). 
rely in challenges before binding national courts of appeal in the Caribbean as well as the Eastern Caribbean Court of Appeal, the Privy Council in London, and eventually the Caribbean Court of Justice. The strategy had worked before. A decision of the European Court of Human Rights in 1989 found that undue delay and conditions of death row could eventually render an otherwise constitutional sentence cruel and degrading. ${ }^{3}$ It was followed over the next decade by decisions arising out of such diverse jurisdictions as Canada, Jamaica, India, and Zimbabwe. ${ }^{4}$

The constitutions of former British colonies in the Caribbean and Africa are in pari materia with one another, created from a template used by departing colonial officials at Lancaster House in London where most constitutional negotiations hurriedly took place on the eve of independence. ${ }^{5}$ The fundamental rights portions of the constitutions are heavily based on the European Convention of Human Rights, which applied to Britain's colonies when the Convention went into force in 1953 and lapsed at independence. ${ }^{6}$ Almost all of these constitutions contain a right to life provision that is clawed back by a subclause specifically saving the death penalty. ${ }^{7}$ In addition, every constitution contains a clause prohibiting torture and cruel, inhuman, or degrading treatment and punishment. ${ }^{8} \mathrm{~A}$ constitutional challenge to the mandatory death penalty rests on the interplay between these two clauses. Anti-death penalty advocates argued that the constitutions only prevent challenge to the death penalty per se, and not textually to the mandatory nature of the death penalty. As a result, courts could find that a mandatory death penalty qualifies as cruel and inhuman punishment since it could be disproportionately harsh; classifying all murders the same even though all are not equally heinous. ${ }^{9}$

Anti-death penalty advocates succeeded on another track as well. Because the mandatory death penalty provides for an automatic sentence of death upon

3. Soering v. United Kingdom, 161 Eur. Ct. H.R. (ser. A) (1989), reprinted in 28 I.L.M. 1063 (1989).

4. Catholic Comm'n for Justice \& Peace v. Attorney-Gen. (1993) L.R.C. 277 (Zimb. S.C.); Triveniben v. State of Gujarat (1989) 1 S.C.J. 383 (India); United States v. Burns [2001] 1 S.C.R. 283 (Can.); Pratt and Morgan v. Attorney-Gen. of Jam. (1993) UKPC 1, [1994] 2 A.C. 1 (P.C.).

5. William Dale, The Making and Remaking of Commonwealth Constitutions, 42 INT'L \& COMP. L.Q. 67 (1993).

6. JenNifer WidNER, Building The Rule of Law: Francis Nyalali and the RoAD to JUDICIAL INDEPENDENCE IN AFRICA 161 (2001).

7. See, e.g., Bahamas Const. art. 16(1); Botswana Const. art. 4(1); Jamaica Const. art. 14(1); GHANA CONST. art. 13(1); Nigeria CoNST. art. 33(1); ZIMBABWE CONST. art. 12(1); c.f. NAMIBIA CONST. art. 6; SOUTH AFR. CONST. art. 11.

8. See, e.g., BAHAMAS CONST. art. 17(2); Botswana CONST. art. 7(1); JAMAICA CONST. art. 17(2); GHANA CONST. art. 15(2); NAMIBIA CONST. art. 8(2); NigERIA CONST. art. 34(1)(a); SOUTH AFR. CONST. art. 12(1); ZIMBABWE CONST. art. 15.

9. See, e.g., Reyes v. The Queen, [2002] UKPC 11, [2002] 2 A.C. 235 (P.C.) (appeal taken from Belize). 
conviction of murder, no sentencing hearing takes place. Courts have interpreted this as a violation of the right to a fair trial, another right that appears in every common law constitution in the Caribbean and Sub-Saharan Africa, which should include the right to present mitigating evidence on a defendant's behalf in a sentencing hearing. ${ }^{10}$ The United Nations Human Rights Committee, the Inter-American Commission on Human Rights, and the Privy Council in London, then the highest court for most Commonwealth Caribbean nations, accepted this argument in a series of challenges. ${ }^{11}$ Both lines of jurisprudence have the same two holdouts: Malaysia and Singapore, which are also former British colonies. The constitutions of these two countries do not include the right to a fair trial or protections against cruel, inhuman, or degrading punishment. ${ }^{12}$ Although the mandatory death penalty has been extinguished in most of the Caribbean, it still survives in Southeast Asia.

This Article will turn first to the two major common law retentionist powers that have invalidated the mandatory death penalty: the United States and India. These decisions provided legal groundwork for launching a series of challenges in the Caribbean. This Article then distinguishes the jurisprudence arising from Malaysia and Singapore, which have resisted challenges for reasons that are peculiar to their constitutional regimes. Finally, this Article analyzes the three most recent decisions invalidating the mandatory death penalty, arising from the Constitutional Court of Malawi, the Supreme Court of Uganda, and the Court of Appeal of Kenya. Each of these three decisions has made a unique contribution to the body of global common law death penalty jurisprudence. As mandatory death penalty challenges advance in half a dozen more African countries, these three decisions will become especially important as persuasive authority. The result will be a death penalty regime harmonized across borders, in which the death penalty is confined only to the rarest and most serious cases, incorporating international human rights norms in sentencing proceedings.

\section{PROLOGUE: THE UNITED STATES AND INDIA}

The first coordinated challenge to the mandatory nature of the death penalty began in the United States. The Eighth Amendment of the United States Constitution forbids "cruel and unusual punishments." ${ }^{\text {"I3 }}$ In two five-tofour Supreme Court decisions in 1976, the United States abolished the common law mandatory death penalty in Woodson $v$. North Carolina and a more limited

10. See infra note 30 .

11. Id.

12. See SingaPore Const. arts. 9-16; Malaysia Const. arts. 5-13.

13. Although the Eighth Amendment originally applied only to the Federal Government, it was applied to the states via the Incorporation Clause of the Fourteenth Amendment in the 1962 case Robinson $v$. California, triggering a long series of challenges to state death penalty schemes throughout the 1970s. See Robinson v. California, 370 U.S. 660 (1962). 
statutory mandatory death penalty in Roberts v. Louisiana. ${ }^{14}$ Although North Carolina's death penalty scheme was in constitutional danger because it included the common law offenses of accomplice liability and felony murder, thus automatically dispensing a death sentence for defendants who did not possess actual intention to kill, observers had predicted that Louisiana's more narrowly-tailored statute requiring actual rather than constructive intent would survive ${ }^{15}$ However, the same five Justices that struck down the North Carolina statute in Woodson voted to strike down Louisiana's statute in Roberts. ${ }^{16}$ Eleven years later in Sumner v. Shuman, the U.S. Supreme Court invalidated a Nevada statute mandating the death penalty for prisoners who committed first degree murder while already under a sentence of life imprisonment, the narrowest and most defensible class of cases. ${ }^{17}$ Through these cases, the Supreme Court made clear that any non-discretionary death sentence was unconstitutional.

In all three decisions, the Court's reasoning was the same: the mandatory death penalty simultaneously permitted too little discretion in the sentencing process, and too much. ${ }^{18} \mathrm{~A}$ mandatory death sentence exacerbated the problem of jury nullification because juries acquit defendants at higher rates in mandatory regimes in order to avoid death sentences. ${ }^{19}$ When fact-finders decide guilt and sentence simultaneously, they risk merging the two decisions, acquitting a guilty defendant in order to avoid a death sentence. As a result, the sentencing discretion ordinarily granted to the fact-finder is transferred to other, less transparent, actors. For example, if prosecutors believe the death penalty is not warranted, they can prosecute for manslaughter or non-capital murder. Similarly, appellate courts review more robustly in sentencing inquiries, and executive clemency bodies grant clemency at high rates. A trial judge, after weighing evidence and interpreting witness candor and demeanor, is especially well-placed to determine a defendant's sentence. By constraining a judge's sentencing discretion at trial, a mandatory death penalty makes sentencing more arbitrary and opaque.

A closely related factor from the Court's reasoning in the three decisions was that a mandatory death penalty failed to appropriately individualize a sentence to the relevant aspects of the character and record of the defendant. ${ }^{20}$ A mandatory sentence treats all individuals as "a faceless, undifferentiated mass

14. Woodson v. North Carolina, 428 U.S. 280 (1976); Roberts v. Louisiana, 428 U.S. 325 (1976).

15. John W. Poulos, The Supreme Court, Capital Punishment and the Substantive Criminal Law: The Rise and Fall of Mandatory Capital Punishment, 28 ARIZ. L. REV. 143, 187-88 (1986).

16. Roberts v. Louisiana, 428 U.S. 325 (1976).

17. Sumner v. Shuman, 483 U.S. 66 (1987).

18. Woodson, 428 U.S. at 303; Roberts, 428 U.S. at 335; Sumner, 483 U.S. at 74-75.

19. Woodson, 428 U.S. at 303.

20. Woodson, 428 U.S. at 304; Roberts, 428 U.S. at 333; Sumner, 483 U.S. at 75. 
to be subjected to the blind infliction of the penalty of death. ${ }^{.21}$ Because death was qualitatively different from other criminal sentences, it required special care: the "fundamental respect for humanity" underlying the Eighth Amendment required consideration of the person of the offender and the circumstances of the crime. ${ }^{22}$ Other safeguards notwithstanding, the clear concern was that a defendant could receive a disproportionately harsh sentence for a crime, a violation of the Eighth Amendment.

In 1983, the Supreme Court of India followed the Woodson Court's lead. In Mithu v. State of Punjab, the Indian court found that the mandatory sentence offended constitutional rights on grounds similar to the American court. ${ }^{23}$ In addition, the Mithu Court found that the legislature could not remove sentencing discretion from judges and require them to inflict death sentences in all murder cases. ${ }^{24}$ This was the origin of a separation of powers argument against the mandatory sentence. A legislature cannot delegate criminal sentencing discretion, a traditional judicial function, to legislative or executive actors. ${ }^{25}$ Mithu, the functional equivalent of Sumner $v$. Shuman because it involved the constitutionality of the mandatory death penalty for homicide for life-term prisoners, foreordained a shift in Indian criminal sentencing policy. Beginning with Singh (Macchi) v. State of Punjab, the Court required judges to balance aggravating and mitigating circumstances in determining a criminal sentence. ${ }^{26}$ With the Woodson and Mithu lines of cases, the mandatory death penalty retreated from the major retentionist common law powers.

\section{SUCCESSFUL EXPERIMENT: THE COMMONWEALTH CARIBBEAN}

In the past decade, the mandatory death penalty has been overturned in nearly every common law Caribbean nation. ${ }^{27}$ The near-extinction of the penalty is the result of a coordinated series of challenges brought initially before the United Nations Human Rights Committee and the Inter-American Human Rights System with the intention of forming a body of persuasive jurisprudence that could be used in binding national court systems. ${ }^{28}$ These early challenges were based on Articles 6.1 and 6.2 of the International Covenant on Civil and Political Rights and the mirror clauses in the American Convention on Human Rights, which uphold the right to life and limit the death

21. Woodson, 428 U.S. at 304.

22. Id.

23. Mithu v. State of Punjab, 2 S.C.R. 690 (1983) (India).

24. Id. at 692 .

25. Id. at 692-93.

26. Singh (Macchi) v. State of Punjab, 3 S.C.R. 413 (1983) (India).

27. Novak, Kenya, supra note 1, at 293.

28. Id. 
penalty to only "the most serious crimes." 29 In both challenges, the fatal factor was that the mandatory death penalty was not individually tailored to fit the crime and could result in the execution of those without actual intent to kill through felony-murder or accomplice liability. These were not considered to be "most serious crimes" within the scope of the treaties. ${ }^{30}$ In the seminal case Edwards v. Bahamas, the Inter-American Commission on Human Rights found that the mandatory death penalty violated the right to fair trial in addition to the right to life under the American Declaration of the Rights and Duties of Man. ${ }^{31}$ Within several years, these challenges produced settled law in the Commonwealth Caribbean. ${ }^{32}$

This early, non-binding jurisprudence developed a body of persuasive law available to national constitutional courts. As with the international treaties, every Caribbean constitution contains a provision upholding the right to life with a death penalty exception, or savings clause, a provision prohibiting cruel and inhuman punishment, and a provision upholding the right to a fair trial. ${ }^{33}$ Through the interplay of these three clauses, anti-death penalty advocates could challenge the mandatory death penalty for murder. Caribbean constitutions contain an added layer of complexity: a clause forbidding constitutional challenges to forms of punishment in existence at the time of independence from Great Britain on the grounds that these punishments violated the

29. International Covenant on Civil and Political Rights, arts. 6.1-6.2, Dec. 19, 1966, 999 U.N.T.S. 85; Organization of American States, American Convention on Human Rights, art. 4, Nov. 22, 1969, O.A.S.T.S. No. 36.

30. Thompson v. St. Vincent and the Grenadines, Comm. No. 806/1988, U.N. Doc. CCPR/C/70/D/806/1998 (2000) (UNHRC); Kennedy v. Trinidad and Tobago, Comm. No. 845/1999, U.N. Doc. CCPR/C/67/D/845/1999 (2002) (UNHRC); Baptiste v. Grenada, InterAm. C.H.R., Report No. 38/00 (2000); McKenzie v. Jamaica, Case 12.023 Inter-Am. C.H.R., Report No. 41/00 (2000); Hilaire, Constantine \& Benjamin v. Trinidad \& Tobago, Inter-Am. Ct. H.R. (ser. C) No. 94/02 (June 21, 2002); Boyce \& Joseph v. Barbados, Inter-Am. Ct. H.R. (ser. C) No. 169/07 (Nov. 20, 2007).

31. Edwards v. Bahamas, Case 12.067 Inter-Am. Comm'n H.R., Report No. 48/01 (2001), citing American Declaration on Rights and Duties of Man, adopted at Ninth Annual International Conference of American States, Bogotá Colombia, 1948, art. 1.

32. See also Chan v. Guyana, Comm. No. 913/2000, U.N. Doc. CCPR/C/85/D/913/2000 (2006) (UNHRC); Lamey v. Jamaica, Case 1 1.826, Inter-Am. Comm'n H.R., Report No. 49/01 (2001); Knights v. Grenada, Case 12.028, Inter-Am. C.H.R., Report No. 47/01 (2001); Thomas v. Jamaica, Case 12.183, Inter-Am. C.H.R., Report No. 127/01 (2001); Cadogan v. Barbados, Inter-Am. Ct. H.R. (ser. C) No. 204/09 (Sept. 29, 2009).

33. A non-exhaustive sampling of these provisions follows: for death penalty savings clauses, see, e.g. ANTIGUA \& BARBUDA CONST. art. 4(1); BAHAMAS CONST. art. 16(1); BELIZE Const. art. 4(1); Dominica ConST. art. 2(1); ST. KITTs \& NEVIS ConST. art. 4(1); ST. LUCIA CONST. art. 2(1); for cruel and inhuman punishment provisions, see, e.g. BARBADOS CONST. art. 15(1); GUYANA CONST. art. 141(1); GRENADA CONST. art. 5(1); ST. VINCENT \& GRENADINES Const. art. 5; TRINIDAD \& TOBAGo CONST. art. 5(2)(b); for fair trial provisions, see, e.g. Bahamas Const. art. 20; DOMINICA CONST. art. 8; JAMAICA Const. art. 20; ST. KITTS \& NEVIS CONST. art. 10; ST. LUCIA CONST. art. 8. 
fundamental rights provisions of the constitutions. ${ }^{34}$ Of the twelve Commonwealth constitutions, eight possess a "partial" savings clause limited solely to judicial punishments while three possess a "general" savings clause preventing constitutional challenge to any law in force at the time of independence. ${ }^{35}$ Only Belize, the last to receive independence in 1981, had a clause that expired five years after independence. ${ }^{36}$ By then, broad savings clauses were perceived to be constitutional anachronisms-constraints on developing notions of constitutionalism. ${ }^{37}$

In early 2000, the Judicial Committee of the Privy Council in London (then the court of final resort for most of the Commonwealth Caribbean) accepted a petition from the Belize Court of Appeal, which had upheld the mandatory death penalty in a constitutional challenge. ${ }^{38}$ The Privy Council combined it with a petition from the Eastern Caribbean Court of Appeal arising from Saint Kitts and Nevis, Saint Vincent and the Grenadines, and Saint Lucia, which had invalidated the penalty. ${ }^{39}$ The Privy Council did not distinguish among the countries; it found all of the mandatory death penalty provisions to be unconstitutional, holding that a sentence that did not permit mitigating evidence could be disproportionately harsh and thus, cruel and inhuman. ${ }^{40}$ The Privy Council also found that executive clemency discretion could not save a mandatory death penalty, as trial judges were in a better position to assess evidence and witness credibility. ${ }^{41}$ The Belizean case Reyes $v$. Queen remains the seminal Privy Council decision on the mandatory death penalty and has since been extended to most of the Caribbean.

For the three countries that possessed "general" savings clauses Barbados, Jamaica, and Trinidad - the question was closer. In 2003, although two five-judge panels of the Privy Council had invalidated the mandatory death

34. Many African independence constitutions contained similar clauses, but unlike Caribbean constitutions, few of these constitutions survive. In most countries, they have been replaced by more modern constitutions. Dale, supra note 5, at 80 . However, the Kenyan constitution had a partial savings clause until 2010. KENYA CONST. art. $74(2)(1969$, as amended to 1997).

35. See, e.g., ANTIGUA \& BARBUdA Const. art. 7(2); BaHAMAS Const. art. 17(2); GrenADA CONST. art. 5(2); GUYANA CONST. art. 141(2) (partial savings clauses); $c . f$. BARBADOS CONST. art. 26(1); JAMAICA CONST. art. 26(8); TRINIDAD \& TOBAGO CONST. art. 6(1) (general savings clauses).

36. BeLIZE CONST. art. 21.

37. See generally Saul Lehrfreund, International Legal Trends and the 'Mandatory' Death Penalty in the Commonwealth Caribbean, 1 OXFORD UNIV. CoMmW. L.J. 171, 185 (2001).

38. Reyes v. The Queen, [2002] UKPC 11, [2002] 2 A.C. 235 (appeal taken from Belize).

39. The Queen v. Hughes, [2002] UKPC 12, [2002] 2 A.C. 259 (appeal taken from St. Lucia); Fox v. The Queen, [2002] UKPC 13, [2002] 2 A.C. 284 (appeal taken from St. Kitts \& Nevis).

40. Reyes, [2002] UKPC 11, [2002] 2 A.C. 235.

41. Id. 
penalty for ordinary murder in Trinidad and Tobago ${ }^{42}$ and for felony murder in Barbados, ${ }^{43}$ both decisions were reversed by the full Council. According to the Council, although a "partial" savings clause preventing challenge to judicial punishments did not prevent challenge to the mandatory death penalty because it was only a manner of sentencing and not a "punishment" per se, the mandatory death penalty was saved under "general" savings clauses that preserved all laws in existence at the time of independence. ${ }^{44}$ Consequently, the Privy Council upheld the mandatory death penalty for Barbados and Trinidad and Tobago. However, the Council found that Jamaica's mandatory death statute postdated independence because it was revised to narrow the scope of the sentence and, consequently, it was not saved. ${ }^{45}$ Barbados has discussed the possibility of making the death penalty non-mandatory, and the penalty continues to survive in Trinidad and Tobago. ${ }^{46}$

As part of a broader campaign against the mandatory death penalty in Trinidad and Tobago, the London-based Death Penalty Project and the University of the West Indies commissioned a survey of public opinion, to discern the level of public support commanded by a mandatory death penalty as opposed to a discretionary death penalty. ${ }^{47}$ The survey authors commissioned a representative sample of 1,000 residents, a large sample for the country's size, and asked them three hypothetical questions about a felony murder, a domestic murder, and a drug murder, each with two examples. One example included a possible mitigating factor and the other did not include the mitigating factor. ${ }^{48}$ The results were unsurprising. Although $89 \%$ of Trinidadians favored the death penalty, only $26 \%$ favored the current mandatory death penalty law. ${ }^{49}$ The survey results suggested that the mandatory death penalty obscured problems of policing and investigations by over-punishing the small proportion of cases successfully won by the prosecution (often domestic murder in which the

42. Khan v. Trinidad \& Tobago, [2003] UKPC 79, [2005] I A.C. 374, rev'd by Griffith v. Trinidad \& Tobago, [2004] UKPC 58, [2005] 2 A.C. 235.

43. Roodal v. Trinidad \& Tobago, [2003] UKPC 78, [2005] 1 A.C. 328, rev'd by Boyce v. The Queen, [2004] UKPC 32, [2005] 1 A.C. 400 (appeal taken from Barb.) and Matthew v. Trinidad \& Tobago, [2004] UKPC 33, [2005] 1 A.C. 433.

44. See Boyce, [2004] UKPC 32, [2005] 1 A.C. 400; see also Matthew, [2004] UKPC 33, [2005] 1 A.C. 433.

45. Watson v. The Queen, [2004] UKPC 34, [2005] 1 A.C. 472 (appeal taken from Jam.).

46. Barbados Death Penalty: Will There Be an Amendment or Abolition, TRIVESTER NEWS (May 4, 2010), http://www.trivester.com/world/americas/caribbean/barbados/news/interamerican-court-human-rights/abolition-of-death-penalty/100504/.

47. See generally Roger Hood \& Florence SeEmungal, Public OPINION ON THE Mandatory Death Penalty in Trinidad: A Report to the Death Penalty Project and the RIGHTS ADVOCACY PROJECT OF THE UNIVERSITY OF THE WEST INDIES FACULTY OF LAW (Death Penalty Project: 2011).

48. Id. at vii.

49. Id. at vii-viii. 
perpetrator was known, and usually related, to the victim). ${ }^{50}$ Indeed, because the most brutal murders such as drug or gang-related murders often went unpunished, a mandatory death penalty did not necessarily correlate with the most serious crimes. ${ }^{51}$ Sixty-three percent of respondents favored a discretionary death penalty, and $73 \%$ believed that the abolition of the death penalty would bring about more murder convictions because a jury would not be forced to choose between manslaughter and death. ${ }^{52}$ All of these findings reflect well-known weaknesses of mandatory death penalty regimes and have important implications for other jurisdictions in the developing world.

\section{THE HOLDOUTS: MALAYSIA AND SINGAPORE}

Uniquely in the common law world, Malaysia and Singapore have upheld their mandatory death penalty regimes from constitutional challenge. ${ }^{53}$ Both countries have historically high rates of execution, particularly for higherincome countries as wealth is generally correlated to abolition. ${ }^{54}$ The political culture in both countries contributes to this phenomenon: a strong executive balanced with a relatively weak judicial power, a law and order ethos on the part of the government, and an intolerance of political dissent. ${ }^{55}$ Although the constitutions of both countries delineate fundamental rights, these rights do not include the right to be free from cruel, inhuman, or degrading treatment or punishment, or the right to a fair trial in broad form, despite the presence of limited components of these rights such as a ban on double jeopardy and arbitrary arrest. ${ }^{56}$ Both countries allow broad derogations and suspensions of certain civil liberties to a much broader degree than elsewhere in the common law world if "necessary or expedient in the interest of security." "Th Th constitutional structure is different from the bulk of former British colonies in Africa and the Caribbean, and has failed to provide a basis for bringing a challenge to the mandatory death sentence.

Malaysia and Singapore are also unique in the common law world

50. Id. at 3 (indicating that domestic-related murders accounted for $36 \%$ of all persons convicted of murder and sentenced to death). By contrast, gang-related murders or murders where the body was "dumped" accounted for $33 \%$ of the recorded killings but accounted for only $2 \%$ of the convictions for murder and manslaughter. Id. at 2 . The report also undermined a proposed policy of creating a new, statutorily limited class of murder subject to the mandatory death penalty, such as violent felonies. $I d$. at 35 .

51. Id. at 2 .

52. Id. at viii.

53. David T. Johnson \& Franklin E. Zimring, The Next Frontier: National Development, Political Change, ANd the Death Penalty In Asia 306 (2009).

54. Id. at 413.

55. Id. at 420 .

56. See Singapore Const. arts. 9-16; MALAYSIA CONST. arts. 5-13; Michael Hor, The Death Penalty in Singapore and International Law, 8 SINGAPORE Y.B. INT'LL. 105, 113 (2004).

57. SINGAPORE CONST. arts. 149-51; MALAYSIA CONST. arts. 149-50. 
because they possess the mandatory death penalty for drug trafficking, which accounts for a disproportionately high percentage of actual executions in both countries. ${ }^{58}$ The penalty has been criticized by both the legal community and the medical community as falling too heavily on foreign nationals, especially migrant workers, and on drug runners and "mules" rather than drug lords. ${ }^{59}$ Although the mandatory death sentence for drug trafficking was originally upheld by the Privy Council in the 1981 case, Ong Ah Chuan v. Public Prosecutor, the case was overruled by Reyes $v$. Queen and its progeny. ${ }^{60}$ Nonetheless, the decision forms the bedrock of Malaysian and Singaporean constitutional defenses to the mandatory death penalty. Malaysian courts upheld the constitutionality of the mandatory death penalty for drug trafficking in Public Prosecutor v. Lau Kee Hoo (1983), ${ }^{61}$ and Singapore did so in Nguyen Tuong Van v. Public Prosecutor (2004) ${ }^{62}$ In the latter case, the Singapore Court of Appeal found that customary international law did not import a ban on inhuman punishment into Singaporean constitutional law, and the Court rejected a separation of powers challenge to the penalty. ${ }^{63}$

In 2010, the Singapore Court of Appeal revisited the constitutionality of mandatory death for drug trafficking in Yong Vui Kong v. Public Prosecutor. The Court interpreted Woodson, Mithu, and the Caribbean jurisprudence in great detail and distinguished them on the basis of Singapore's different constitutional structure. ${ }^{64}$ As in Nguyen Tuong Van, the Court found that although the European Convention of Human Rights applied to Singapore for ten years prior to independence, the rights delineated in the Convention were not applicable to Singapore after independence and were disavowed in the independence constitution. ${ }^{65}$ The Court also rejected an equal protection of the law argument, in which the appellant argued that the schedule of penalties based on the quantity of the drugs being trafficked was arbitrary, including

58. Rick Lines, The Death Penalty for Drug Offences: A Violation of International Human Rights Law, Powerpoint Presentation to the Commission on Narcotic Drugs (Mar. 10, 2008), available at $\mathrm{http}: / / \mathrm{www}$.ihra.net/files/2010/06/21/Lines-DeathPenaltyCND2008.pdf.

59. Yvonne McDermott, Yong Vui Kong v Public Prosecutor and the Mandatory Death Penalty in Singapore: A Dead End for Constitutional Challenge?, 1 INT'L J. HUM. RTS. \& DRUG POL'Y 35, 50-51 (2010); Griffith Edwards et al., Drug Trafficking: Time to Abolish the Death Penalty, 8 InT'L J. Mental Health Addiction 616, 618 (2010).

60. Ong An Chuan v. Public Prosecutor, [1981] A.C. 648 (appeal taken from Sing.).

61. Public Prosecutor v. Lau Kee Hoo, Malayan L. J. 157 (1983) (F.C.). In Lau Kee Hoo, the Federal Court of Kuala Lumpur refused to follow the Indian case of Mithu v. State of Punjab and instead relied on the Privy Council in Ong An Chuan and an earlier precedent, Runyowa v. The Queen, an appeal arising from the Federal Court of Rhodesia and Nyasaland upholding the mandatory nature of the death penalty for politically-motivated arson. Id. at 160-63. See also Runyowa v. The Queen, [1967] 1 A.C. 26 (appeal taken from Fed. of Rhodesia \& Nyasaland).

62. Nguyen Tuong Van v. Public Prosecutor, 1 S.L.R. 103 (2005) (Sing. C.A.).

63. Id. at $9 \llbracket 86-87,95-98$.

64. Yong Vui Kong v. Public Prosecutor, [2010] SGCA 20 (Sing. C.A.).

65. Id. at 36-38. 
penalties up to the mandatory sentence of death for a person carrying 15 grams of heroin, 30 grams of cocaine, 250 grams of methamphetamines, or 500 grams of cannabis. ${ }^{66}$ According to the Court, despite similar mental states, traffickers carrying different quantities of narcotics were not equal and the law properly distinguished among them. ${ }^{67}$

Consequently, the mandatory death sentence in both countries is a slippery target for anti-death penalty advocates because the reasoning of the constitutional challenges is circular. The appellant argued that the mandatory death penalty was an inhuman punishment under international customary law even though Singapore specifically disavowed the existence of such customary law and failed to incorporate such a prohibition into the constitution. The same is true of the due process challenge to the mandatory death penalty. The Singapore Court of Appeal has rejected analogies to the constitutional protections of fair trial rights in other Commonwealth countries because such rights are specifically excluded in Singapore's constitution. ${ }^{68}$ The Court is one of the few national courts to have rejected outright constitutional challenges on the basis of delay or conditions on death row. Of the two countries, Singapore is likely the more unyielding in its defense of the mandatory death penalty, but the sentence looks to remain legal and active in both countries for the foreseeable future. Nonetheless, the impact of this jurisprudence is limited given the unique constitutional structures in both countries-strong executives, weak fundamental rights protections, and isolation from human rights treatiesthat make these countries clearly distinguishable from the Caribbean and African lines of cases.

\section{THE NEW FRONTIER: COMMON LAW AFRICA}

With the contraction of the mandatory death penalty in the Caribbean, and despite the holdouts in Southeast Asia, an international network of lawyers and experts led by the London-based Death Penalty Project and their partners launched a series of challenges to the mandatory death penalty in African common law nations with the explicit goal of incrementally working toward total abolition of capital punishment. These challenges have been successful so far in Malawi, ${ }^{69}$ Uganda, ${ }^{70}$ and now Kenya. ${ }^{71}$ Similar litigation is pending or

66. JOHNSON \& ZIMRING, supra note 53, at 411.

67. Yong Vui Kong, [2010] SGCA 20 at 65.

68. See Jabar v. Public Prosecutor, I S.L.R. 617 (1995) (Sing. C.A.) (rejecting analogies to recent case law in India and Jamaica based on the differing wording of their constitutional texts).

69. See Novak, Malawi Uganda, supra note 1.

70. See id.

71. See Novak, Kenya, supra note 1. 
planned in at least six other common law African countries. ${ }^{72}$ Each of these decisions relied heavily on foreign and international precedent, including the Caribbean case law, and each has made an important contribution in their own right to the corpus of global death penalty jurisprudence.

As in the Caribbean, these challenges are premised on the similarity among common law African constitutional structures. British officials working with African nationalist leaders meticulously drafted at least thirty-three complete and final constitutions with varying levels of public input. ${ }^{73}$ Within a decade, most of these constitutions had been abrogated, amended, or replaced, but fundamental rights provisions tended not to be heavily altered. Currently, every common law African constitution other than South Africa and Namibia contains a death penalty savings clause on the model of the European Convention on Human Rights: "No one shall be deprived of his life intentionally save in the execution of a sentence of a court following his conviction of a crime for which this penalty is provided in law."74 This savings clause model is intended to prevent direct legal challenge to the death penalty. African constitutions possess similar provisions prohibiting inhuman punishment and supporting the right to a fair trial as well as constitutional procedures for seeking clemency or pardon from the executive.

This sharing occurred with substantive law as well. Former British colonies in Africa received similar penal and criminal procedure codes, based on the 1899 Queensland, Australia penal code and the 1877 Gold Coast procedure code, with improvements mediated through the legal system of British India. ${ }^{75}$ Consequently, the mandatory death penalty passed intact to British Africa without any benefit from the legal reforms that swept Great Britain itself in the 1950s and 1960s. The mandatory death penalty, however, was always too harsh for post-colonial African legal culture, particularly as many African countries outside of the Islamic zone had a spotty tradition of capital punishment prior to the colonial era. ${ }^{76}$ Many common law African countries send enormous numbers of men to death row, but far fewer to the gallows. Hundreds of criminals are placed on death row each year in common law Africa while these same countries average only two to three judicial

72. Death Penalty Project UK, Human Rights Litigation in African Countries, http://www.deathpenaltyproject.org/content_pages/31 (last visited Mar. 29, 2012).

73. William Dale, The Making and Remaking of Commonwealth Constitutions, 42 INT'L \& CoMP. L.Q. 67 (1993).

74. European Convention for the Protection of Human Rights and Fundamental Freedoms, art. 2, Nov. 4, 1950, 213 U.N.T.S. 222, E.T.S. No. 5.

75. Simon Coldham, Criminal Justice Policies in Commonwealth Africa: Trends and Prospects, 44 J. AfR. L. 218,219 (2000).

76. See Lillian Chenwi, Toward the Abolition of the Death Penalty In Africa: A HuMAN Rights PERSPECTIVE 19 (2007); Novak, Malawi Uganda, supra note 1, at 39-43; Novak, Kenya, supra note 1, at 313-14. 
executions per year combined. ${ }^{77}$ The result is a near-uniform constitutional vulnerability that could transform the way that the death penalty is applied throughout the region.

\section{A. The Constitutional Court of Malawi: Kafantayeni}

The Constitutional Court of Malawi invalidated the mandatory death penalty in 2007 in Kafantayeni v. Attorney General $^{78}$ In a targeted challenge, the Court found the penalty violated 1 ) the right to be free from cruel, inhuman punishment because the sentence was not individually tailored to the crime;2) the right to a fair trial because a defendant did not have an opportunity in a judicial proceeding to present mitigating evidence on her behalf; and 3) the right of access to the court system because the defendant did not have a venue through which to appeal guilt and sentence separately. Although the state did not appeal in Kafantayeni, the Supreme Court of Appeal, Malawi's highest court, confirmed the judgment in Jacob (Twoboy) v. State when it found that Malawi's death penalty was no longer mandatory. ${ }^{79}$ The plaintiff in Jacob claimed that he had been acting in a state of temporary insanity induced by a narcotic, which could have qualified as a mitigating circumstance in a discretionary death penalty regime. ${ }^{80}$

As in Uganda and Kenya, the Malawian constitution enshrines the right to life with a specific exception for the death penalty. ${ }^{81}$ According to Malawi's Penal Code, dating from 1930, five crimes carried the death penalty, including treason, rape, murder, armed robbery, and burglary. ${ }^{82}$ However, the penalty was only mandatory for murder. ${ }^{83}$ In deciding that the mandatory death penalty qualified as cruel and inhuman punishment and was not specifically saved, the Constitutional Court found the Belizean case of Reyes v. Queen to be particularly persuasive ${ }^{84}$ Like the Woodson Court, the Malawian Constitutional Court determined that the lack of individualized sentencing discretion could result in the infliction of capital punishment on a defendant whose crime did not warrant the penalty. ${ }^{85}$ In addition to Reyes, the decision cited other

77. See, e.g., Mutiso v. Republic, Crim. App. No. 17/2008 (July 30, 2010) (Kenya C.A.), at If 14.

78. Kafantayeni v. Attorney-Gen., [2007] MWHC 1 (Malawi).

79. Jacob v. Republic, MSCA Crim. App. No. 16/2006 (July 19, 2007) (Malawi S.C.A.) (unrep.).

80. Id.

81. Malawi Const. art. 16.

82. Malawi Law Commission, Discussion Paper No. 1, Human Rights Under the CONSTITUTION OF THE REPUBLIC OF MALAWI 2 (2006), available at www.lawcom.mw/docs/ discussion_paper1_human_rights.pdf.

83. Mwiza Jo Nkhata, Bidding Farewell to Mandatory Capital Punishment: Francis Kafantayeni and Others v Attorney General, 2007 MaLAWI L.J. 103, 110.

84. Kafantayeni, [2007] MWHC 1 at 6.

85. Id. at 9. 
Caribbean jurisprudence extensively, as well as the South African case Makwanyane, in which the Constitutional Court of South Africa found the death penalty unconstitutional. ${ }^{86}$

As an additional ground for invalidating the mandatory death penalty, the Constitutional Court found that the penalty violated the right to a fair trial and that an accused person has a right to an individualized sentencing determination based on all the evidence presented. ${ }^{87}$ The Court specifically held that the International Covenant on Civil and Political Rights states that every person convicted of a crime must be permitted effective appellate review, and because a mandatory death penalty determines guilt and sentence simultaneously, the penalty precludes a higher court from reviewing a sentence on its own merits. ${ }^{88}$ For this, the judges cited the seminal case Edwards v. Bahamas. ${ }^{89}$ The Court also found that a mandatory death penalty violated the right of access to justice as enshrined in Malawi's constitution, constituting a third ground for invalidating the penalty. ${ }^{90}$ Interpreting the right more broadly than the right to a fair trial, the Court found that because the mandatory death penalty does not permit a sentencing hearing and precludes appellate review of a sentence, it effectively denies an accused person's right to access the judicial system for resolving legal disputes. ${ }^{91}$ Unlike the inhuman punishment and fair trial grounds, the Court raised the right of access to justice sua sponte; the issue was not raised by the parties themselves. ${ }^{92}$

Several months later, the Supreme Court of Appeal confirmed the result in a separate case, Jacob v. Republic, an appeal against sentence. ${ }^{93}$ The Supreme Court affirmed Kafantayeni in its entirety and indicated that it was "largely persuaded" by the jurisprudence of the Privy Council ${ }^{94}$ Using a more textual approach than the Constitutional Court, the Supreme Court interpreted Article 42 of the constitution, the "right to adduce and challenge evidence," as a basis for finding that the mandatory death penalty violated an accused's right to a fair trial by not permitting consideration of mitigating circumstances. ${ }^{95}$ The result of the two cases, according to the Court, was that every prisoner on death row in Malawi was entitled to an individualized sentencing hearing. ${ }^{96}$

Even though the Malawi Constitutional Court avoided reliance on the

86. Id. at 10.
87. Id. at 12 .
88. Id. at $12-13$.
89. Kafantayeni, [2007] MWHC 1 at 13 , citing Edwards v. Bahamas, Case 12.067 , InterAm. Comm'n H.R., Report No. 48/01, OEA/Ser.L/V/II.111, doc. 20 (2001).

90. Id. at 14 , citing MALAwI CONST. art. 41 (2).

91. Id. at 12 .

92. Id. at 6.

93. See Jacob v. Republic, MSCA Crim. App. No. 16/2006 (July 19, 2007) (Malawi

S.C.A.) (unrep.).

94. Id. at 3-5.

95. Id. at 6.

96. Id. 
right to life provision of the Malawi Constitution in Kafantayeni, the decision has been interpreted by lower courts as standing for the proposition that the right to life is inviolable except in the application of a discretionary death penalty. ${ }^{97}$ In Republic v. Cheuka, the Malawi High Court (a trial-level court) convicted a police officer of manslaughter due to police brutality, holding that extrajudicial police killing was a violation of the right to life. ${ }^{98}$ According to the High Court, the right to life is inviolable except for the death penalty, and even that exception was narrowly construed by the Constitutional Court in Kafantayeni. ${ }^{99}$ In partial reliance on Kafantayeni, the High Court judge wrote that "the right to life ranks supreme to all other rights guaranteed by [the] Constitution," the "most fundamental of all rights in that it is a prerequisite for the enjoyment or exercise of all other rights." 100 The judge analyzed the jurisprudence of the European Court of Human Rights and the United Nations Code of Conduct for Law Enforcement, and concluded that the extrajudicial killing at the hands of a police officer fell below international law enforcement standards. ${ }^{101}$ This case strongly suggests that lower courts in Malawi will view the decision broadly and apply the rationale to other contexts.

Progress in resentencing death row prisoners after Kafantayeni, however, has been minimal. As of 2010, of the nearly 200 persons on death row in Malawi, only a handful had even consulted a lawyer, and not a single resentencing hearing had taken place. ${ }^{102}$ While many common law African countries suffer from a shortage of legal representation, the shortage in Malawi is particularly acute. ${ }^{103}$ Malawi's legal aid system is overwhelmed, as only a handful of legal aid lawyers serve the entire country. ${ }^{104}$ Although the Malawian constitution contemplates legal aid at state expense, the provision is in danger of becoming a platitude. ${ }^{105}$ As in many other countries in Sub-Saharan Africa, Malawi is experimenting with allowing non-lawyers such as paralegals and law

97. See Malawi Const. art. 16 (right to life provision).

98. Republic v. Cheuka et al., Crim. Case No. 73/2008 (Apr. 2, 2009) (Malawi H.C.).

99. Id.

100. Id.

101. Id.

102. Chesa Boudin, Making an Impact in Malawi, ChICAGo LAWYer MAGAZINE, May 27, 2010, available at $\mathrm{http}: / / \mathrm{www} . c h i c a g o l a w y e r m a g a z i n e . c o m / A r c h i v e s / 2010 / 06 / 01 / 7530$.aspx.

103. For statistics on the legal aid shortage in Africa, see David McQuoid-Mason, Legal Aid in Nigeria: Using National Youth Service Corps Public Defenders to Expand the Services of the Legal Aid Council, 47 J. AFr. L. 107, 108 n.6 (2003). See also Harri Englund, Towards a Critique of Rights Talk in New Democracies: The Case of Legal Aid in Malawi, 15 DISCOURSE \& SoC'Y 527, 532 (2004) (noting that because of Malawi's traditional status as a source of labor employment for Southern African mines, much of the legal aid shortage is in labor and employment disputes, which could be mitigated through stronger trade unions and alternative dispute resolution).

104. Hillery Andersen, Justice Delayed in Malawi's Criminal Justice System: Paralegals v. Lawyers, 1 INT'L J. CRIM. JUST. SCI. 1, 2 (2006).

105. MALAWI CONST. art. 42(1)(c). 
students to shoulder some of the burden in representing defendants who are entitled to review of their sentences. ${ }^{106}$

\section{B. The Supreme Court of Uganda: Kigula}

Unlike the targeted appeal in Malawi, the Ugandan challenge was an omnibus challenge to the death penalty. The appellants argued that 1) the death penalty was an inhumane punishment and alternatively, that the mandatory sentence of death was unconstitutional; 2) hanging was impermissible as a mode of execution; and 3) a long delay on death row could make an otherwise constitutional sentence unconstitutional. ${ }^{107}$ The decision of the Ugandan Constitutional Court in Kigula v. Attorney General essentially split the difference and found that the mandatory death penalty and inordinate delay were unconstitutional, while upholding a discretionary death penalty and hanging as a method of execution. ${ }^{108}$ Unlike the Malawian court, the Ugandan majority opinion interpreted Ugandan law much more closely and engaged in a more textual-based constitutional analysis. The concurrences used a range of constitutional interpretive methods, including culturalist arguments, ${ }^{109}$ framers' intent, ${ }^{110}$ and popular opinion. ${ }^{111}$ A dissenting opinion argued that the criminal justice system provided sufficient safeguards against arbitrariness, including legal aid for indigent defendants, ${ }^{112}$ the right of automatic appeal, ${ }^{113}$ and the right to petition for clemency. ${ }^{114}$

Both parties cross-appealed the Constitutional Court decision before the Supreme Court of Uganda in Attorney General v. Kigula. The Supreme Court voted unanimously to uphold the death penalty per se, but to strike down the mandatory death sentence for murder and unconstitutional delay and conditions on death row. ${ }^{115}$ The Court also voted six to one to turn away the challenge to hanging as a method of execution. ${ }^{116}$ As with the Constitutional Court, the

106. Boudin, supra note 102. This would require loosening unauthorized practice of law restrictions. For more on the topic of limited practice for non-lawyers in the African context, see Andrew Novak, The Globalization of the Student Lawyer: A Law Student Practice Rule for Indigent Criminal Defense in Sub-Saharan Africa, 3 HuM. RTS. \& GLOBALIZATION L. REV. 33 (2009).

107. Kigula et al. v. Attorney Gen., Constitutional Petition No. 6/2003 at 2 (2005) (Uganda C.C.).

108. Id. at 61-63.

109. Id. at 116 .

110. Id. at 68-69.

111. Id. at 117-18 (Twinomujuni, J., concurring); 17-23 (Byamugisha, J., concurring).

112. Id. at $159-64$.

113. Id. at 169-73.

114. Id. at 159-164, 169-173 (Mpagi-Bahigeine, J., dissenting); 179 (Kavuma, J., dissenting).

115. Attorney Gen. v. Kigula et al., [2009] UGSC 6 at 63-64 (Uganda).

116. Id. at $62-63,65$. 
Supreme Court engaged in a variety of constitutional interpretive methods. The Court particularly emphasized the conclusions of the Constitutional Review Commission more than ten years earlier to determine the drafters' intent, finding that the "inclusion of the death penalty in the Constitution was therefore not accidental or a mere afterthought. It was carefully deliberated upon."117 Textually, the Constitution favored a finding upholding the death penalty per se since it not only included a death penalty savings clause, but also a right to legal representation for capital defendants at the expense of the state and the right to seek clemency. ${ }^{118}$ These provisions did not bear on the specific issue of the mandatory death penalty, however, and the Constitutional Review Commission conclusions could be read as favoring a discretionary death penalty. ${ }^{119}$

The Supreme Court agreed with the lower court's finding that a fair trial included both conviction and sentencing stages and that a defendant is entitled to present mitigating evidence and have the sentence subject to appellate review. ${ }^{120}$ The Court also reached the separation of powers argument that the Malawian court did not reach and found that the penalty was unconstitutional because a mandatory death penalty ties the hands of judges in their inherent constitutional power to determine both conviction and sentence. ${ }^{121}$ Regarding the argument that the mandatory death penalty constituted cruel and inhuman punishment, the Supreme Court took a slightly different approach than the lower court though both interpreted domestic precedent much more extensively than the Malawian court did. The Constitutional Court heavily relied on Kyamanywa, which invalidated adult corporal punishment as inhuman and degrading. ${ }^{122}$ The Supreme Court relied instead on $A b u k i$, in which the Court had struck down banishment as a penalty for witchcraft. ${ }^{123}$

Considering delay and conditions of death row, the Supreme Court looked in detail at the "demeaning" conditions at Luzira Prison. ${ }^{124}$ The Court held that a prisoner has a right to sufficient time in which to exercise all avenues of appeal before execution, but cannot be unduly kept in prison for an indefinite period and essentially serve a lengthy prison sentence before a death sentence. ${ }^{125}$ Finally, the Court upheld hanging as a method of execution from

117. Id. at 77 .

118. UGANDA CONST. arts. 22(1), 28(3)(e), 121(5).

119. Kigula, [2009] UGSC 6 at 32-33.

120. Id. at $41,43-44$.

121. Id. at 45 .

122. Kyamanywa v. Uganda, Const. Ref. No. 10 of 2000 (Dec. 14, 2001) (Uganda C.C.) (referred from Uganda Supreme Court in Crim. App. No. 16 of 1999, dated July 4, 2000). Kyamanywa was later confirmed by the Supreme Court in Oryem Richard \& Another v. Uganda, [2003] UGSC 30.

123. Abuki v. Attorney Gen., [1997] UGCC 5, aff'd by Attorney Gen. v. Abuki, [2001] 1 L.R.C. 63 (Uganda S.C.).

124. Kigula, [2009] UGSC 6 at 48.

125. Id. at 56-57. 
constitutional challenge. ${ }^{126}$ This may have been the weakest part of the decision. The Court found that the mandatory death penalty was a sentence in itself and consequently fell within the scope of $A b u k i$, which laid out guidelines for determining whether a sentence constituted cruel and inhuman punishment. On the issue of hanging, however, the Court found that it was only the manner of executing a sentence and not a sentence in itself and consequently fell outside the scope of Abuki. ${ }^{127}$ This distinction is, at best, a fine one. In fact, it conflicts with the long line of Privy Council jurisprudence holding that the mandatory death penalty is not a judicial punishment subject to the partial savings clause in many Caribbean constitutions, but rather simply a method of sentencing. ${ }^{128}$ The dissent by Justice Egonda-Ntende laid out in detail the harsh effects of hanging and argued that, like the mandatory death penalty, hanging was not specifically saved under the constitution and could be found unconstitutional. ${ }^{129}$ Given the tension in the majority opinion, hanging as a method of execution in common law countries continues to be constitutionally vulnerable even though the argument did not win support from the Ugandan courts.

Kigula has led to a revolution in Ugandan sentencing law, despite some inconsistencies in the landmark decision's real-world application. In April 2010, the Ugandan Court of Appeal upheld two death sentences after considering mitigating factors such as a three-year delay in prison before trial, remorse for the murder of a relative, and dependents of the defendants. ${ }^{130}$ According to the Court, however, "considering the injuries received and the weapon used, the conduct of the appellants before and after commission of the offence, [irresistibly] point to premeditated murder." ${ }^{, 131}$ In that case, the testimony showed that the defendants lay in wait for the victim and attacked her with pangas six times. These were circumstances that the justices felt outweighed the mitigating factors. In a similar case, the Court ruled that aggravating factors outweighed mitigating factors where the defendant violently murdered his seventy-year-old step-grandmother. ${ }^{132}$ In mitigation, the defendant-appellant argued that he was a first-time offender, that he was on remand for four years before conviction, and that he had a wife and five children. ${ }^{133}$ The defendant also argued a defense that he was protected by the

126. Id. at 59 .

127. Id. at 60 .

128. See, e.g., Reyes v. The Queen, [2002] UKPC 11, [2002] 2 A.C. 235 (appeal arising from Belize).

129. Kigula, [2009] UGSC 6 at 70, 80, 91, 96.

130. Omasige Calvin \& Okia James v. Uganda, Crim. App. No. 179 of 2003 (Apr. 6, 2010) (Uganda C.A.).

131. Id.

132. Feni Yasin v. Uganda, Crim. App. No. 51 of 2006 (June 28, 2010) (Uganda C.A.).

133. Judges in a number of the cases consider the defendant's age as a mitigating factor. In Feni Yasin, the defendant was 48 years old, but it is not clear whether the age is being offered because the defendant was young or old. Id. 
defenses of intoxication and provocation, which the Court specifically rejected ${ }^{134}$ Interestingly, the Court treated the defenses of intoxication and provocation as legal defenses and not in the same way as the other factors offered in mitigation. ${ }^{135}$ Although the case was not an ideal one, a later case may present the opportunity to more carefully delineate how a judge should weigh legal defenses and mitigating factors where both are raised. ${ }^{136}$

The Ugandan Court of Appeal reversed a death sentence in June 2010 where mitigating factors outweighed aggravating factors in the case of Jino Adama v. Uganda. ${ }^{137}$ In that case, the defendant-appellant was convicted of armed robbery, a capital crime. He was not convicted of murder, and pleaded in his defense that he was a first-time offender, that he had been in prison for over three years before conviction, and that he had a wife and four children. ${ }^{138}$ The Court found that the trial judge had properly convicted the defendant of armed robbery, but determined that a death sentence was inappropriate because even though three gunshots were fired, no life was lost. ${ }^{139}$ In addition, the defendant appeared remorseful. ${ }^{140}$ Consequently, the Court sentenced the defendant to fifteen years imprisonment retroactive to 2006 when he was convicted. ${ }^{141}$ Because this case presented fairly strong facts for armed robbery, the emphasis of the justices on the fact that no one was killed suggests that the Court will be skeptical of death sentences for armed robbery in the future. In October 2011, the Ugandan newspaper The Monitor reported that the Ugandan High Court reduced three death sentences for convicts in aggravated robbery trials to imprisonment of fifteen and twenty years, respectively. ${ }^{142}$ This supports the hypothesis that, now freed of the mandatory death requirement, judges in Uganda will be skeptical of death sentences in non-murder cases. ${ }^{143}$

In a series of cases, the Ugandan Court of Appeals reversed the murder convictions of defendants who had been sentenced to death. In June 2010, the Court of Appeal reversed not only a death sentence, but a murder conviction, where the prosecution failed to prove malice aforethought when the defendant used the handle, rather than the blade, of a weapon to hit the victim, a young

134. Id.

135. Id. at 3.

136. In particular, the case left open the question of whether a failed defense could be a mitigating factor even if it does not exculpate the defendant.

137. Adama Jino v. Uganda, Crim. App. No. 50 of 2006 (June 23, 2010) (Uganda C.A.).

138. Id. at 3 .

139. Id. at 8 .

140. Id.

141. Id.

142. Anthony Wesaka, Three Convicts on Death Row Survive Hangman, THE MONITOR, Oct. 20, 2011.

143. On the other hand, the Ugandan High Court handed out discretionary death sentences after consideration of mitigating circumstances. See, e.g., Uganda v. Aurien James Peter, Crim. Case No. 12/2010 (Nov. 28, 2010), [2010] UGHC 102. 
child. ${ }^{144}$ Although the Court addressed the mitigating factors of the defendant as a first-time offender and a young father, it reversed the murder charge and convicted him of manslaughter given the parts of the body affected and the number and nature of the injuries on the victim, which underscored a lack of intent to kill. ${ }^{145}$ The Court was also troubled by the fact that the assessors in the trial unanimously recommended a manslaughter sentence to the trial judge, and consequently sentenced the defendant to fifteen years in prison, retroactive to when the defendant was first convicted. ${ }^{146}$ In another case, the Ugandan Court of Appeal reversed the conviction outright and acquitted and freed the defendant due to contradictions in testimony and the failure of a proper initial investigation. ${ }^{147}$ Although the Court noted several factors in mitigation of a death sentence, emphasizing the defendant as a first-time offender, the Court ultimately excluded some hearsay evidence and found that "the learned trial judge erred in convicting the appellant on scanty circumstantial evidence adduced by prosecution," which fell far short of the standard of proof required. ${ }^{148}$ While a practitioner often appeals both guilt and sentence in murder cases, judges do not have a chance to reach the sentencing issue when the guilt inquiry leads to reversal.

By ruling that all prisoners on death row for longer than three years should have their sentences commuted to life imprisonment "without remission," the Ugandan Supreme Court in Kigula created an interpretive problem since the Prisons Act states that "imprisonment for life" should be construed as twenty years imprisonment rather than "whole life" imprisonment. ${ }^{149}$ In addition to the twenty-year rule under the Prisons Act, prison officials retained some discretion to shorten the sentence for good behavior. ${ }^{150}$ After the Ugandan Court of Appeal upheld a conviction of child rape and a sentence of life imprisonment in Stephen Tigo v. Uganda, the Supreme Court squarely confronted the issue of the meaning of life imprisonment under Section 47(6) of the Prisons Act, which states that a sentence of life imprisonment should be deemed to be twenty years. ${ }^{151}$ In Tigo, the Supreme Court clarified Kigula by indicating that whole life or natural life imprisonment was warranted for those prisoners who were spared the death

144. Patrick Abicopongo v. Uganda, Crim. App. No. 86 of 2005 at 5 (June 23, 2010) (Uganda C.A.).

145. Id. at 6 .

146. Id.

147. Geoffrey Ongune Kasule v. Uganda, Crim. App. No. 19 of 2004 (June 28, 2010) (Uganda C.A.).

148. Id. at 5 .

149. Jamil Ddamulira Mujuzi, Life Imprisonment in International Criminal Tribunals and Selected African Jurisdictions-Mauritius, South Africa and Uganda 272-75 (May 13, 2009) (LL.D. Thesis, University of the Western Cape).

150. Prisons Act, Act 17 of $2006 \S \S 84-86$ (Uganda).

151. Stephen Tigo v. Uganda, [2009] UGCA 6, appeal dismissed; Tigo v. Uganda, Crim. App. No. 170 of 2003 (Mar. 23, 2009) (Uganda S.C.). 
penalty, rather than imprisonment for twenty years, because Kigula intended to impose the next most severe sentence and specific prison sentences for longer than twenty years are not uncommon in the country. ${ }^{152}$ Although the Court ruled that Stephen Tigo's imprisonment should be twenty years based on other grounds, the Court was clear that it would be an absurd result if life imprisonment were construed to be a lesser sentence than terms of imprisonment for longer than twenty years. ${ }^{153}$ As Mujuzi writes, however, the decision conflicts with a growing international trend to limit life imprisonment terms. $^{154}$

The legal systems of both Uganda and Malawi have recently come under intense international scrutiny because of the criminalization of homosexuality. In Malawi, a homosexual couple was sentenced to fourteen years imprisonment with hard labor for engaging in sodomy. ${ }^{155}$ After the sentence was upheld on appeal, international pressure forced President Bingu wa Mutharika to pardon the couple. ${ }^{156}$ In Uganda, the Anti-Homosexuality Bill of 2009 authorized a mandatory death sentence for persons convicted of "aggravated" sodomy or HIV transmission, eliciting worldwide condemnation despite the mandatory death provision's facial unconstitutionality after Kigula ${ }^{157}$ While it is unlikely that either country will increase criminal penalties of this nature, particularly given each country's international HIV donor networks, both cases underscore the extent to which harsh criminal punishments for homosexuality retain popular support. Like Malawi, Uganda has also faced legal aid shortages in post-Kigula challenges. A new initiative, developed in October 2011 and funded by the Uganda-based Foundation for Human Rights Initiatives and the British government, will provide free legal assistance to fifteen inmates on death row who are challenging their sentences. ${ }^{158}$

\section{The Court of Appeal of Kenya: Mutiso}

On July 30, 2010, the Kenyan Court of Appeal handed down Mutiso v. Republic, invalidating the mandatory death sentence for murder. ${ }^{159}$ Godfrey

152. Tigo v. Uganda, Crim. App. No. 170 of 2003 (Mar. 23, 2009) (Uganda S.C.).

153. Id.

154. Mujuzi, supra note 149 , at 283-290.

155. Jamil Ddamulira Mujuzi, Discrimination Against Homosexuals in Malawi: Lessons from the Recent Developments, 11 INT'L J. DISCRIMINATION \& L. 150, 156 (2011).

156. Malawi Gay Couple Released After Presidential Pardon, BBC News, May 30, 2011, available at http://www.bbc.co.uk/news/10194057.

157. Anti-Homosexuality Bill, No. 18 of 2009, Uganda Gazette No. 47, Sept. 25, 2009. See also Cecilia Strand, Kill Bill! Ugandan Human Rights Organizations' Attempts to Influence the Media's Coverage of the Anti-Homosexuality Bill, 13 CULTURE, HEALTH \& SEXUALITY 917,91719 (2011).

158. Ephraim Kasozi \& Betty Ndagire, Death Sentence Inmates to Get Free Legal Services, THE MONITOR, Oct. 15, 2011.

159. Mutiso v. Republic, Crim. App. No. 17/2008 (July 30, 2010) (Kenya C.A.). 
Mutiso was convicted of a premeditated murder involving a dispute over petty larceny. ${ }^{160}$ With four highly corroborative fact witnesses against only Mutiso's unsworn statement in his defense, the trial court judge found him guilty of murder with intent to cause bodily harm and gave him the only sentence permitted under the Penal Code: death by hanging. ${ }^{161}$ In August 2009, Kenyan President Mwai Kibaki commuted the sentences of all death row prisoners in Kenya, including Mutiso. ${ }^{162}$ In addition, the attorney general conceded that the mandatory death penalty was not constitutional. ${ }^{163}$ Nonetheless, the Court found that Mutiso had standing and that the case was ripe for adjudication. ${ }^{164}$

The Court of Appeal invalidated the mandatory death penalty for murder on the grounds that the sentence violated the right to life, that it constituted cruel, inhuman, and degrading punishment, and that it violated the right to a fair trial. ${ }^{165}$ Like the courts in Malawi and Uganda, the Court cited the seminal case Reyes $v$. Queen for the inhuman punishment ground. ${ }^{166}$ The Kenyan court's framing of the right to life violation was unique. The Malawian court did not reach the issue, ${ }^{167}$ and the Ugandan court avoided it by finding that the death penalty was saved and thus could not violate the right to life. ${ }^{168}$ According to the Kenyan court, where the mandatory death penalty fell on defendants who did not necessarily merit the special penalty of death, a right to life violation would occur. ${ }^{169}$ Constitutional litigation over the right to life is particularly prolific in Kenya, and a number of seminal legal debates concerning abortion access, domestic violence, and environmental rights have arisen out of the Court of Appeal and constitutional reform process. ${ }^{170} \mathrm{~A}$ week after the decision in Mutiso, Kenyan voters went to the polls and overwhelmingly ratified a new constitution. ${ }^{171}$ The scope of the right to life provision, particularly concerning abortion access, proved to be one of the most contentious aspects of the new constitutional draft. ${ }^{172}$ The new constitution contains a death penalty savings clause, although it is arguably vaguer than the former constitution and will no doubt lead to continued incremental death

160. Republic v. Mutiso, Crim. Case No 55/2004 (Feb. 29, 2008) (Kenya H.C.).

161. Id. In total, nine witnesses testified for the prosecution, including an expert witness.

162. Mutiso, Crim. App. No. 17/2008, at 10.

163. Id.

164. Id. at $\uparrow 11$.

165. Id. at $9 \uparrow 32-34$.

166. $I d$. at $\uparrow 32$.

167. C.f. Kafantayeni v. Attorney-Gen., [2007] MWHC 1 at 6-7 (Malawi).

168. Attorney Gen. v. Kigula et al., [2009] UGSC 6 at 36-37 (Uganda).

169. Mutiso, Crim. App. No. 17/2008 at ๆ 34.

170. See, e.g., Waweru v. Republic, (2006) 1 K.L.R. 677, 677, 681, 684 (H.C.K) (Kenya); Eunice Brookman-Amissah \& Josephine Banda Moyo, Abortion Law Reform in Sub-Saharan Africa: No Turning Back, 12 Reproductive HEALTH MATTERS 227, 231 (2004).

171. See Jeffrey Gettleman, Kenyan Constitution Opens New Front in Culture Wars, N.Y. TIMEs, May 14, 2010, at A6.

172. Id. 
penalty challenges. ${ }^{173}$

The decision had other similarities to those arising from Uganda and Malawi as well. Although the Court did not explicitly follow Uganda in finding that the mandatory death penalty violated the separation of powers because of legislative constraints on judicial sentencing discretion, it did note the argument in appellant's submissions and quoted this holding from Kigula. ${ }^{174}$ Perhaps the Court's caution was warranted because the separation of powers was drastically altered under Kenya's new constitution. The Court did dismiss the argument that sentencing discretion was unnecessary because of executive pardon and clemency power, in accordance with Reyes $v$. The Queen and most other courts, including the Ugandan court. ${ }^{175}$ Like Kigula and Kafantayeni, the Kenyan Court of Appeal cited a wide array of foreign jurisprudence. The Court noted it was "satisfied" that the foreign case law was "persuasive in our jurisdiction and we make no apology for applying" it. ${ }^{176}$ Like the Ugandan court, the Kenyan court issued strong dicta indicating that the mandatory death penalty for crimes other than murder was also unconstitutional, including treason, robbery with violence, and attempted robbery with violence--three crimes that have a long history of political prosecutions in Kenya. ${ }^{177}$ The Court also provided strong dicta receptive to a death row syndrome challenge in the future, on the model of the Zimbabwean case Catholic Commission, a challenge that also proved successful in Kigula. ${ }^{178}$

Finally, the Court successfully bridged the gap between Kenya's independence constitution and the 2010 constitution. Unlike Malawi and Uganda, which have more modern constitutions, Kenya's original constitution possessed a Caribbean-style partial savings clause. ${ }^{179}$ The Court interpreted the clause in accordance with the Caribbean cases Reyes, Fox, and Hughes, holding that the mandatory death penalty was a matter of sentencing, not a judicial punishment, and thus was not saved. ${ }^{180}$ Although the Court resisted an omnibus South African-style death penalty challenge, it was satisfied that the mandatory death penalty would not be resurrected under the new constitution. ${ }^{181}$ To this end, the Court based its decision on three fundamental rights that had nearly exact parallels in both constitutions. ${ }^{182}$ Like the Ugandan Supreme Court, the Kenyan court looked to drafters' intent, noting that the new constitution "was

173. C.f. ConstrTUTION, art. 71(1) (1969), art. 29(f) (2010) (Kenya).

174. Mutiso, Crim. App. No. $17 / 2008$ at 97 34-35.

175. Id. at 14.

176. Id. at 932 .

177. Id. at of 36 .

178. Id. at 911 16-18.

179. Constitution, art. 74(2) (1969) (Kenya) (there is no equivalent in the 2010 constitution).

180. Mutiso, Crim. App. No. $17 / 2008$ at $\$ 32$.

181. Id. at 926.

182. CONSTITUTION, arts. 71(1), 74(1), 77(1) (1969) (Kenya); ConstiTUTION, arts. 23(1), 29(f), 50(1) (2010) (Kenya). 
arrived at through a consultative and public process," and consequently one could assume "that the people of Kenya, owing to their own philosophy and circumstances, have resolved to qualify the right to life and retain the death penalty in the statute books." ${ }^{183}$ The Court appeared to close the door on a direct challenge to the constitutionality of the death penalty even under the new constitution.

The High Court, the trial-level court in Kenya that possesses original jurisdiction over murder cases, clarified Mutiso in Evanson Muiruri Gichane v. Republic in which the defendant was sentenced to death for attempted robbery with violence. ${ }^{184}$ Although the trial court based its decision overturning the death sentence in part on an apparent contradiction in the penal code in which attempted robbery with violence triggered a mandatory death sentence under one provision and only seven years imprisonment under another, the trial court also rested its decision on the Mutiso holding. ${ }^{185}$ To that end, the trial court extended the ban on mandatory death sentences to attempted robbery with violence. Although in Mutiso the Court of Appeal had claimed to close the door on a direct challenge to the constitutionality of the death penalty under the new constitution, it did not engage a searching comparison between the old constitution and the new one. The death penalty under the old constitution was clearly saved: "71(1) No person shall be deprived of his life intentionally save in execution of the sentence of a court in respect of a criminal offence under the law of Kenya of which he has been convicted."186

In comparison, however, the new constitution is ambiguous:

26(1) Every person has the right to life. 26(2) The life of a person begins at conception. 26(3) A person shall not be deprived of life intentionally, except to the extent authorised by this constitution or other written law. 26(4) Abortion is not permitted [with exceptions omitted]. ${ }^{187}$

The right to life provision under the new constitution contains two ambiguities. First, the clause that could be construed as "saving" the death penalty is a separate clause from, and not a modifying subclause of, the grammatically absolute right to life. Second, 26(3) appears to be circular, because it states that a person shall not be deprived of life except where constitutionally authorized, and provides no constitutional authorization except for abortion exceptions. According to one of the experts on the Constitutional Review Commission, this ambiguity was intentional, to reconcile Kenyan

183. Mutiso, Crim. App. No. 17/2008 at $9 \uparrow$ 23-24.

184. Evanson Muiruri Gichane v. Republic, Crim. App. No. 277 of 2007 (Dec. 10, 2010) (Kenya H.C.).

185. Id., slip op. at 4-6.

186. Constitution, art. 71(1) (1969) (Kenya).

187. Constitution, art. 26 (2010) (Kenya). 
popular opinion with global trends toward the death penalty. ${ }^{188}$

On June 10, 2011, High Court Judge John Matthew Anyara Emukule found the death penalty unconstitutional under the new constitution. ${ }^{189}$ After finding the accused guilty of murder, Judge Emukule turned to the sentencing. Although his decision is inelegant, he highlighted both of the ambiguities in Article 26 of the new constitution. ${ }^{190}$ In accepting the mitigating factors of the case, including the defendant's young age (he was twenty at the time of his arrest) and the ethnic and political dimension of the murder, Judge Emukule held "that Article 26(2) (on deprivation of life) is inconsistent with the right to life preserved under Article 26(1) of the Constitution ...."191 Consequently, he sentenced the accused to thirty years imprisonment with an option of parole after twenty years. ${ }^{192}$ The case remains on appeal.

In December 2011, High Court Judge M. Warsame came to the opposite decision of Judge Emukule, not only upholding the constitutionality of the death penalty, but also rejecting Mutiso and finding that the new constitution authorizes a mandatory death penalty ${ }^{193}$ Judge Warsame compared the wording of the old constitution to the new constitution and found that the new constitution actually expanded the application of the death penalty because the phrase "the extent authorized by this constitution or other written law" in article $26(3)$ of the new constitution was broader than "save in execution of the sentence of a court" in article 71(1) of the former constitution. ${ }^{194}$ His decision went further, rejecting the belief that the death penalty was cruel and inhuman punishment and holding that the death sentence was the only punishment available to a conviction of murder. He made his disagreement with Judge Emukule explicit:

It is also alleged that death penalty is a cruel and inhuman punishment but what about the loss of life, as a result of the unlawful act of the accused. In my view loss of someone's life is equal and amounts inhuman treatment. The person who is

188. E-mail from member of Committee of Experts, to author (June 21, 2011) (on file with author).

189. Republic v. John Kimita Mwaniki, Crim. Case No. 116 of 2007 (June 10, 2011)(Kenya H.C.).

190. He also noted an additional one, which is that the right to life is not among the rights that may not be limited under Article 25 (rights to freedom from torture and cruel, inhuman, and degrading treatment; freedom from slavery; right to a fair trial; and right to habeas corpus). See ConstituTion, art. 25 (2010) (Kenya).

191. Mwaniki, Crim. Case No. 116 of 2007 at 26.

192. Id. Judge Emukule again reiterated his opposition to the death penalty under the new constitution in dicta in Republic v. Milton Kabulit et al., Crim. Case No. 115/2008 (Jan. 26, 2012) (Kenya H.C.).

193. Republic v. Dickson Mwangi Munene, Crim. Case No. 11 of 2009 (Dec. 10, 2011) (Kenya H.C.).

194. Id. 
responsible for the loss must pay for it in equal measure or commensurate to the suffering of the victim or his family.... I also think the recent decision of the Court of Appeal [Mutiso] and that of my brother Justice Emukule is a significant step in the wrong direction. My position, is that, the law as currently in existence provides for death penalty notwithstanding the noble view of my brother Justice Emukule... The mandatory use of the word 'shall' gives me no option or route other than to impose death penalty. Consequently I sentence the two accused person to suffer death as prescribed by law. ${ }^{195}$

This decision is highly aberrational. In nearly all other capital sentencing cases at the High Court, including both murder cases in which the High Court sits as a trial court and in robbery with violence cases in which the High Court sits as an appellate court, the accused was permitted to offer mitigating evidence. ${ }^{196}$

Despite this split among High Court judges, guidance from the Kenya Court of Appeal thus far has been limited. In March 2012, the Kenya Court of Appeal upheld two discretionary death sentences that were imposed on defendants after they had the opportunity to present mitigating evidence. ${ }^{197}$ This is in keeping with the spirit of Mutiso that the death penalty should remain a lawful sentence so long as it was not mandatory. Nonetheless, the Court of Appeal has not yet received a clear constitutional challenge to the death penalty per se based on the wording of the new constitution, so opportunity still exists to expand Mutiso.

Kenya's 2010 constitution established the Supreme Court of Kenya, an additional level of appeal from the current Court of Appeal, as part of a sweeping program of judicial reform including reducing case backlogs, improving rural court access, ensuring impartiality of judicial officers, and

195. Id.

196. See, e.g., Vincent Jared Ogutu v. Republic, Crim. App. No. 89/2010 (Nov. 1, 2011) (Kenya H.C.); Boaz Onyango et al. v. Republic, Crim. App. 53 \& 55/2010 (Sept. 23, 2011) (Kenya H.C.). In Ogutu and Boaz, the High Court received appeals from magistrate's courts because these cases concerned the death penalty for robbery with violence. The High Court is the court of first instance in murder cases, but not in robbery with violence cases, which is why they are designated "Crim. App." instead of "Crim. Case." As a consequence, both Ogutu and Boaz were remanded to the lower courts. For murder cases at the High Court, see Republic v. Jacob Juma Msituni, Crim. Case No. 10/2008 (Mar. 12, 2012) (Kenya H.C.) and Republic v. Mbaruk Mwangeti, Crim. Case No. 15/2008 (Mar. 16, 2012) (Kenya H.C.). In both of those cases, the High Court judges weighed the evidence in the first instance and then proceeded to a sentencing phase where the defendant was permitted to offer mitigating evidence in accordance with Mutiso.

197. Benard Mutua Matheka v. Republic, Crim. App. No. 155/2009 (Mar. 15, 2012) (Kenya C.A.); James Maina Magare et al. v. Republic, Crim. App. No. 224/2010 (Mar. 16, 2012) (Kenya C.A.). Interestingly, the Court of Appeal noted at the end of the Magare judgment that one of the judges on the three judge panel refused to sign the decision. 
implementing paperless appeals. ${ }^{198}$ Currently, the Supreme Court is composed of Chief Justice Willy Mutunga, Deputy Chief Justice Nancy Baraza, and five other justices. Several candidates before the Judicial Services Commission, which is vetting candidates for vacancies in the Kenyan court system, have included judges who explicitly told the panel that they oppose the death penalty based on the wording of the new constitution. ${ }^{199}$ Perhaps the long tradition of political executions in late colonial Kenya, the abuse of due process under the Daniel arap Moi regime, the weakness of a pre-colonial death penalty tradition in Kenya, and the attitudes of the political elites tending toward abolition represent a broader ambivalent public attitude. ${ }^{200}$ If that is the case, and if Justice Emukule's decision is indicative of the attitudes of the current judiciary, then the death penalty may well be struck down in Kenya by the future Supreme Court.

\section{CONCLUSION: THE AFRICAN CONTRIBUTION TO COMPARATIVE DEATH PENALTY JURISPRUDENCE}

The abolition of the mandatory death penalty in the common law world is a case study of how international human rights norms are being installed in domestic constitutional jurisprudence intentionally by a small network of lawyers. Although the challenges are incremental, the stated goal is much larger: to end the death penalty worldwide by fundamentally making it more difficult for prisoners to be placed on death row. African countries appear to be following the emerging global consensus that not all murders are equally heinous and deserving of death, that the right to a fair trial includes a sentencing hearing, and that a sentence disproportionate to a crime is cruel and degrading punishment. African courts have increasingly followed the lead of the Privy Council's Caribbean jurisprudence on the scope of executive clemency and appellate review, on delay and conditions on death row, and on the right to appeal to international and regional human rights tribunals. The settled law of the Caribbean, formed over the course of a decade by challenges to supranational tribunals, national courts, the Privy Council in London, and later the Caribbean Court of Justice, has almost entirely dispensed with the mandatory death sentence in the region. Common law African constitutions are in pari materia with Caribbean constitutions, and the weight of this

198. Protus Onyango, Kenya's Two Female Supreme Court Justices Set to Work, INTERPRESS SeRviCE, Nov. 10, 2011, http://ipsnews.net/news.asp?idnews=105789.

199. Death Penalty Cruel, JSC Told, DaIL Y NATION, July 6, 2011 (noting that magistrate judge seeking elevation to judge told the Commission that the death penalty was unconstitutional and not discretionary); Magistrates Push for Repeal of Death Penalty, DAILY NATION, Aug. 4, 2011 (noting that three additional candidates for High Court judges indicated that the death penalty was unconstitutional).

200. For a summary of the pre-colonial, colonial, and post-colonial history of the death penalty in Kenya, see Novak, Kenya, supra note 1. 
jurisprudence is being imported to the African continent.

At the same time, African countries have made their own contributions to the global body of death penalty jurisprudence, and will likely be cited in later constitutional challenges to the mandatory death sentence. Just as $E d w a r d s v$. Bahamas stands for the proposition that the mandatory death penalty violates the right to a fair trial, and Reyes v. The Queen (Belize) is the seminal case finding that the death penalty is cruel and inhuman punishment, so too will the decisions arising from Kenya, Malawi, and Uganda be cited for their original holdings. Kafantayen $i$ is the first case to hold that the mandatory death penalty violates the right of access to the court system for the resolution of disputes because it does not permit true appellate review of a sentence. Kigula was the first case to explicitly hold that the mandatory death penalty violates the constitutional separation of powers because the legislature was constraining judicial sentencing discretion. Mutiso is the first case to find that because the mandatory death penalty is not specifically saved in the constitution, it violates the right to life. In each of these cases, the courts followed the emerging international consensus on the mandatory death penalty but adopted the international norms to their own domestic contexts.

On February 1, 2012, the Supreme Court of India invalidated the mandatory death penalty for an aggravated homicide provision that was intended to reach terrorist groups operating in India. ${ }^{201}$ This decision, State of Punjab v. Singh (Dalbir), cited global precedent for the proposition that the mandatory death penalty violates the right to a fair trial because it precludes a sentencing hearing for a defendant convicted of murder. ${ }^{202}$ Among the international authorities cited by the Indian Supreme Court were the decisions in Kafantayeni, Kigula, and Mutiso. ${ }^{203}$ The "sharing" of constitutional doctrines, particularly in common law developing countries formerly colonized by Britain, is not a new phenomenon. Many of these countries had expatriate judges and underdeveloped legal doctrines in the decades after independence, and the constitutions drawn up after independence were broadly similar. ${ }^{204}$ The constitution of India, however, was older than those in Africa and did not follow the template precisely, lacking an explicit ban on cruel, inhuman, and degrading punishment. ${ }^{205}$ As a consequence, the Indian Supreme Court in Singh (Dalbir) did more than simply quote case law from Africa, the Caribbean, and elsewhere; the judges performed a searching analysis of the reasoning of other common law courts in order to reach a novel holding based on due process and fair trial rights rather than on the "inhuman punishment" clause. Like the

201. State of Punjab v. Singh (Dalbir), [2012] INSC 84, [2012] 3 S.C.C. 346 (India S.C.).

202. Id.

203. Id. at ๆ 75-82.

204. WIDNER, supra note 6 , at 61 .

205. Based on the due process provisions of the Indian constitution, the Supreme Court of India has found an implicit ban on cruel and unusual punishment similar to the Eighth Amendment of the United States Constitution. Singh (Dalbir), [2012] INSC 84 at $\uparrow 47$. 
African and Caribbean Courts before it, the Indian Supreme Court expanded the boundaries of global death penalty jurisprudence.

The consequences of decisions such as Kafantayeni, Kigula, and Mutiso extend far beyond death penalty cases. Capital sentencing regimes in Malawi, Uganda, and Kenya will require the creation of sentencing standards and a definitive list of aggravating and mitigating factors, and post-mandatory death penalty sentencing litigation has already begun. ${ }^{206}$ In addition, the Privy Council in London has suggested a willingness to strike down mandatory life imprisonment for murder based on the same reasoning as death penalty cases. ${ }^{207}$ The decisions are important statements of judicial independence from the courts that have issued them, particularly in countries that do not have extensive records of invalidating laws that do not comply with international human rights norms. Again, the results are broader. The line of mandatory death challenges shows how a relatively small group of lawyers can take advantage of increasing interdependence among legal systems to help professionalize the legal community in the developing world, to share legal resources and transfer knowledge across borders, and ultimately help ground emerging notions of constitutionalism in postcolonial legal systems. 
. 